\title{
IMPLEMENTASI PENDEKATAN KONTEKSTUAL UNTUK MENINGKATKAN HASIL BELAJAR MATEMATIKA SISWA
}

\author{
Nahor Murani Hutapea \\ Pendidikan Matematika, Universitas Riau \\ E-mail: nahorm.hutapea@lecturer.unri.ac.id
}

\begin{abstract}
Abstrak. Berdasarkan hasil observasi di lapangan, hasil belajar matematika siswa (HBMS) masih rendah. Hal ini dikarenakan kegiatan pembelajaran masih didominasi oleh guru; siswa kurang berperan aktif dalam proses pembelajaran (baik individu atau kelompok); dan siswa kurang diberikan kesempatan untuk menghubungkan apa yang telah dipelajari dengan dunia nyata yang dialami oleh siswa, sehingga proses belajar kurang bermakna. Untuk itu telah dilakukan penelitian tindakan dengan model desain siklus, melalui implementasi pendekatan kontekstual yang bertujuan untuk memperbaiki proses pembelajaran dan meningkatkan HBMS. Penelitian dilakukan di SMP Muhammadiyah 1 Pekanbaru, subjek dalam penelitian ini adalah siswa kelas VII-4 yang terdiri dari 25 siswa dengan tingkat kemampuan heterogen. Instrumen penelitian in adalah perangkat tes HBMS, lembar observasi, dan perangkat pembelajaran. Perangkat pembelajaran terdiri dari rencana pelajaran dan lembar kerja siswa. Data aktivitas dianalisis dengan statistik narasi, HBMS dianalisis dengan statistik deskriptif. Hasil pengamatan kegiatan (guru, siswa) terjadi perbaikan proses pembelajaran setelah tindakan pada siklus pertama dan kedua dan terjadi peningkatan jumlah persentase siswa dari skor dasar ke tes matematika 1 dan dari tes matematika 1 ke tes matematika 2. Kesimpulan dari penelitian ini adalah implementasi pendekatan kontekstual dapat memperbaiki proses pembelajaran dan dapat meningkatkan HBMS di topik himpunan.
\end{abstract}

Kata kunci: Implementasi, Pendekatakan kontekstual, Peningkatan hasil belajar matematika siswa

\section{PENDAHULUAN}

Dalam kurikulum tahun 2013 dinyatakan bahwa tujuan pembelajaran matematika adalah agar siswa (1) memahami konsep matematika; (2) menggunakan penalaran pada pola dan sifat, melakukan manipulasi matematika dalam membuat generalisasi, menyusun bukti, menjelaskan gagasan dan pernyataan matematika; (3) memecahkan masalah, meliputi kemampuan memahami masalah, merancang model matematika, menyelesaikan model dan menafsirkan solusi yang diperoleh; (4) mengkomunikasikan gagasan dengan simbol, tabel, diagram, atau media lain; (5) memiliki sikap menghargai kegunaan matematika dalam kehidupan; (6) memiliki sikap dan perilaku sesuai nilai-nilai matematika dan pembelajarannya; (7) melakukan kegiatan motorik menggunakan pengetahuan matematika; dan (8) menggunakan alat peraga sederhana maupun hasil teknologi untuk melakukan kegiatan-kegiatan matematika (Permendikbud No. 58 Tahun 2014).

Ketercapaian tujuan pembelajaran matematika dapat dilihat dari hasil belajar yang dicapai siswa. Hasil yang diharapkan adalah hasil belajar matematika yang mencapai ketuntasan belajar. Siswa dikatakan tuntas belajar matematika, apabila nilai hasil belajar matematika siswa telah mencapai kriteria ketuntasan minimum (KKM) yang telah ditetapkan sekolah (Permendiknas nomor 20 Tahun 2007 tentang standar penilaian). KKM adalah kriteria ketuntasan belajar minimal yang ditentukan oleh satuan pendidikan dengan mempertimbangkan karakteristik kompetensi dasar yang akan dicapai, daya dukung dan karakteristik siswa. Oleh karena itu, setiap siswa harus mencapai KKM untuk setiap kompetensi dasar mata pelajaran matematika yang telah ditetapkan sekolah.

Kenyataan di lapangan menunjukkan bahwa masih terdapat kesenjangan antara hasil belajar matematika (HBM) yang diharapkan dan HBM yang telah dicapai siswa dalam proses pembelajaran. Informasi dari guru matematika kelas VII-4 SMP Muhammadiyah 1 Pekanbaru, yaitu masih banyak siswa yang belum mencapai KKM yang ditetapkan sekolah (76). Hal ini mengindikasikan bahwa masih banyak siswa kelas VII-4 SMP Muhammadiyah 1 Pekanbaru yang belum tuntas dalam belajar matematika; atau dengan kata lain HBM siswa kelas VII-4 SMP Muhammadiyah 1 Pekanbaru masih rendah.

Salah satu pemicu rendahnya HBM siswa, dikarenakan aktivitas pembelajaran masih didominasi guru (teacher-centered); siswa kurang berperan aktif dalam pembelajaran (baik secara individu maupun kelompok); siswa kurang diberi kesempatan untuk melihat hubungan nyata antara apa yang telah dipelajari dengan dunia nyata yang dialami siswa; siswa kurang diberi kesempatan untuk menemukan 
kembali (reinvention), dan mengkonstruksi sendiri ide-ide matematis, sehingga proses pembelajaran berlangsung kurang bermakna. Sementara, Soedjadi (2000) menyatakan bahwa mengaitkan pengalaman kehidupan nyata anak dengan ide-ide matematika dalam pembelajaran di kelas; penting dilakukan agar pembelajaran bermakna.

Pemicu lainnya, yakni ketika siswa diberikan soal yang berbeda dengan contoh soal, maka siswa berkemampuan tinggi saja yang aktif; beberapa siswa lainnya terlihat bertanya kepada teman sebangkunya, sehingga banyak siswa kurang memahami konsep dari materi yang diberikan. Hal ini menunjukkan bahwa guru hanya memberikan masalah yang penyelesaiannya sesuai dengan contoh soal, sehingga tidak jarang terjadi siswa hanya menerima apasaja yang disampaikan guru tanpa memahami apa maknanya. Pembelajaran seperti ini tidak sesuai dengan Permendiknas nomor 41 tahun 2007 (Permendiknas, 2007); yang menghendaki proses pembelajaran pada setiap satuan pendidikan harus dilakukan secara interaktif, inspiratif, menyenamgkan, menantang, memotivasi siswa untuk berpartisipasi aktif, memberikan ruang yang cukup bagi prakarsa, kreativitas dan kemandirian sesuai dengan bakat, minat, perkembangan fisik dan psikologis siswa.

Untuk mengatasi maslah di atas, perlu dilakikan perbaikan dalam usaha meningkatkan HBM siswa menjadi lebih optimal, yakni dengan meningkatkan kulitas pembelajaran dan memperbaiki proses pembelajaran yang sudah ada dengan pendekatan pembelajaran yang dapat mengaktifkan dan memberi kesempatan kepada siswa melihat hubungan antara apa yang dipelajari dengan dunia nyata yang dialami siswa dilingkungannya dan melibatkan interaksi dan diskusi antar siswa dan antara siswa dengan guru tentang suatu gagasan yang dikembangkan, sehingga wawasan siswa tentang apa yang dipelajarinya dapat berkembang dengan baik yang berimplikasi kepada peningkatan HBM siswa.

Salah satu pendekatan pembelajaran yang dapat meningkatkan keterlibatan siswa secara aktif mengkonstruksi dan menemukan pengetahuannya (baik individu maupun kelompok); melihat hubungan nyata antara apa yang dipelajari dengan dunia nyata dialami siswa; dan meningkatkan HBM siswa adalah pendekatan kontekstual (PK). Hal ini dikarenakan langkah-langkah PK (konstruktivisme, menemukan, bertanya, masyarakat belajar, pemodelan, refleksi, penilaian sebenarnya) dapat membuat siswa belajar menjadi aktif mengkonstruksi dan menemukan pengetahuan mereka (individu maupun kelompok); merefleksi atau merespon tentang apa yang baru dipelajari; dan akhirnya perkembangan pengetahuan dan keterampilan siswa dapat diukur dan dinilai melalui penilaian sebenarnya (Trianto, 2014).

Selain itu, melalui PK dapat diciptakan suatu iklim belajar, yakni siswa mendapat kebebasan dalam berfikir, mengajukan ide-ide, pertanyaan-pertanyaan dan masalah-masalah, sehingga belajar matematika lebih efektif dan bermakna. Selanjutnya, langkahlangkah PK dapat memberikan kesempatan kepada siswa merespon dan menyelesaikan masalah secara bebas dan kreatif. Guru lebih berperan sebagai fasilitator dan mediator untuk mendorong siswa melakukan sendiri aktivitas memecahkan masalah dan mengkomunikasikan konsep-konsep matematika yang diperolehnya melalui pemecahan masalah matematis. Untuk itu telah dilakukan penelitian tentang "Implementasi Pendekatan Kontekstual Untuk Meningkatkan Hasil Belajar Matematika Siswa ".

Dari pendahuluan yang telah diuraikan di atas, maka rumusan masalahnya adalah apakah implementasi pendekatan kontekstual dapat memperbaiki proses pembelajaran dan meningkatkan hasil belajar matematika siswa kelas VII-4 SMP Muhammadiyah 1 Pekanbaru tahun pelajaran 2017/2018 pada materi pokok himpunan; dengan tujuan untuk memperbaiki proses pembelajaran dan meningkatkan HBM siswa kelas VII-4 SMP Muhammadiyah 1 Pekanbaru. Selanjutnya, kontribusi atau manfaat yang diharapkan dari penelitian ini, yakni salah satu alternatif pembelajaran dalam memperbaiki proses pembelajaran dan meningkatkan HBM siswa.

\section{METODE}

Penelitian ini merupakan penelitian tindakan kelas (PTK) dengan desain model siklus sebanyak dua siklus dengan melakukan refleksi awal terlebih dahulu. Siklus pertama terdiri dari tiga pertemuan tatap muka dan satu ulangan harian (UH1). Siklus kedua terdiri dari tiga pertemuan tatap muka dan satu ulangan harian (UH2). Pada setiap siklus dilakukan tindakan, mengacu pada langkah-langkah implementasi PK dan pada siklus kedua tindakan dilakukan berdasarkan hasil refleksi siklus pertama. Arikunto (2012) menyatakan bahwa PTK dilakukan melalui empat tahap, yaitu (1) perencanaan; (2) pelaksanaan; (3) pengamatan; dan (4) refleksi.

Refleksi Awal. Salah satu penyebab rendahnya HBM siswa adalah aktivitas pembelajaran masih didominasi guru (teacher-centered); siswa kurang: (1) berperan aktif dalam pembelajaran (baik secara individu maupun kelompok); (2) diberi 
kesempatan melihat hubungan nyata antara apa yang telah dipelajari dengan dunia nyata dialami siswa; (3) diberi kesempatan untuk menemukan kembali (reinvention); (4) diberi kesempatan mengkonstruksi sendiri ide-ide matematis; dan (5) diberi kesempatan menggunakan daya nalarnya untuk menyelesaikan suatu masalah dengan berbagai strategi, sehingga proses pembelajaran berlangsung kurang bermakna. Sehubungan dengan itu perlu dilakukan tindakan, yaitu implementasi PK untuk memperbaiki proses pembelajaran dan meningkatkan HBM siswa.

Perencanaan Tindakan. Pada tahap ini, peneliti merancang dan mempersiapkan instrumen penelitian, yakni: perangkat pembelajaran dan instrument pengumpul data. Perangkat pembelajaran meliputi: silabus, rencana pelaksanaan pembelajaran (RPP), lembar kerja siswa (LKS); masing-masing untuk tiga pertemuan. Instrumen pengumpul data yang digunakan adalah lembar pengamatan dan seperangkat tes HBM siswa untuk UH1 dan UH2. Untuk skor dasar (SD) siswa diperoleh dari hasil UH materi sebelumnya (Bilangan).

Pelaksanaan Tindakan. Pelaksanaan tindakan merupakan implementasi dari perencanaan. Pada tahap ini, peneliti bertindak sebagai guru dalam melaksanakan proses pembelajaran berpedoman pada RPP. Dalam pelaksanaan pembelajaran dibentuk kelompok kooperatif dengan jumlah 25 siswa, sehingga pada siklus I dan siklus II masing-masing dibentuk 6 kelompok; 5 kelompok beranggotakan 4 siswa (kelompok 1, 2, 4, 5, dan 6) dan 1 kelompok beranggotakan 5 siswa (kelompok 3 ) yang heterogen dalam bidang akademik. Kelompok pada siklus I disusun berdasarkan SD yang diambil dari nilai $\mathrm{UH}$ pada materi sebelumnya (Bilangan).

Pengamatan Tindakan. Pada tahap ini yang bertindak sebagai pengamat adalah guru matematika kelas VII-4 SMP Muhammadiyah 1 Pekanbaru. Pengamatan dilakukan terhadap aktivitas guru dan siswa selama proses pembelajaran berlangsung. Pengamatan dilakukan bersamaan dengan pelaksanaan tindakan. Aspek yang diamati tentang aktivitas guru dan siswa selama proses pembelajaran meliputi kegiatan yang tertuang pada RPP. UH siswa dibuat berbentuk tes uraian hasil belajar.

Refleksi. Pada tahap ini, peneliti dan pengamat (guru) membahas hasil pengamatan pelaksanaan pembelajaran setiap pertemuan. Refleksi ini bertujuan untuk memperbaiki kualitas proses pembelajaran dan mengoptimalkan pelaksanaan tindakan pada pertemuan selanjutnya. Untuk mengumpulkan data dalam penelitian ini digunakan teknik pengamatan dan tes tertulis. Teknik pengamatan digunakan untuk mengumpulkan data tentang aktivitas guru dan siswa dengan cara mengisi lembar pengamatan. Teknik tes tertulis digunakan untuk mengumpulkan data tentang HBM siswa pada materi himpunan melalui UH disetiap akhir siklus. UH1 dilakukan pada akhir siklus pertama, dan UH2 pada akhir siklus kedua.

Analisis data aktivitas guru dan siswa didasarkan dari hasil lembar pengamatan selama pelaksanaan tindakan. Data tersebut dianalisis dengan statistik naratif yang dilihat dari hasil refleksi dengan menemukan dampak dari tindakan yang dilakukan, yakni melihat kekurangan dari kegiatan pembelajaran yang digunakan sebagai refleksi untuk perbaikan pelaksanaan pembelajaran pada pertemuan dalam siklus berikutnya. Analisis data HBM siswa didasarkan dari hasil tes yang dilakukan setelah tindakan (UH1 dan UH2). Data tersebut dianalisis dengan statistik deskriptif.

\section{HASIL DAN PEMBAHASAN}

Hasil analisis deskriptif terhadap data aktivitas guru pada siklus 1 dan 2 (pertiga pertemuan) melalui implementasi pendekatan kontekstual, disajikan pada Gambar 1.

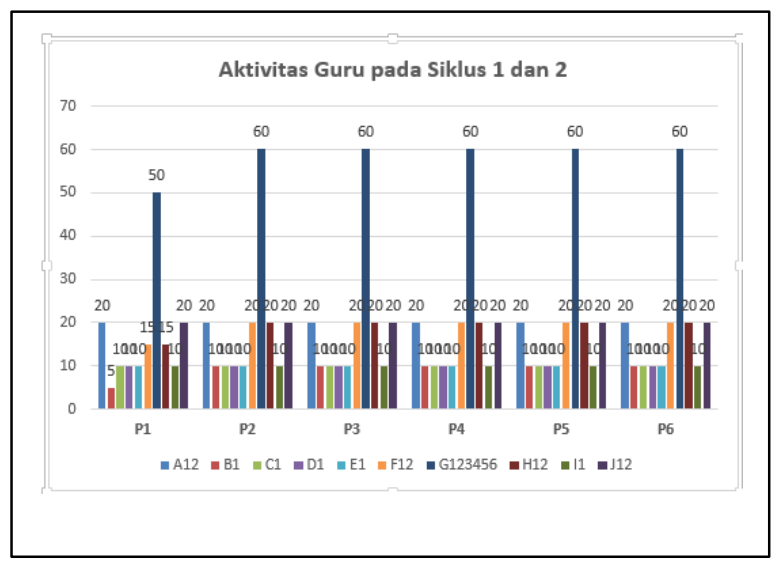

Gambar 1. Aktivitas Guru pada Siklus 1 dan 2

Melalui Implementasi Pendekatan Kontekstual

Keterangan:

$\mathrm{A} 12=$ Indikator A deskriptor 1 dan 2; Indikator A = Menyiapkan siswa secara fisik dan psikis untuk mengikuti proses pembelajaran; Deskriptor $1=$ Guru meminta ketua kelas menyiapkan teman-temannya dan memimpin doa; dan Deskriptor $2=$ Guru mengecek kehadiran siswa.

$\mathrm{B} 1=$ Indikator $\mathrm{B}$ deskriptor 1 ; Indikator $\mathrm{B}=$ Memotivasi siswa; Deskriptor $1=$ Guru memotivasi siswa dengan memberikan 
contoh yang relevan dengan materi yang sedang dipelajari.

$\mathrm{C} 1=$ Indikator $\mathrm{C}$ deskriptor 1 ; Indikator $\mathrm{C}=$ Melakukan apersepsi; Deskriptor $1=$ Guru memberikan apersepsi dengan cara mengingatkan kembali tentang konsep yang berkaitan dengan materi yang dipelajari.

D1 = Indikator D deskriptor 1; Indikator D = Menyampaikan tujuan pembelajaran; Deskriptor 1= Guru menyampaikan tujuan pembelajaran yang akan dicapai siswa.

$\mathrm{E} 1$ = Indikator $\mathrm{E}$ deskriptor 1; Indikator $\mathrm{E}=$ Menyajikan informasi; Deskriptor $1=$ Guru menyampaikan informasi cakupan materi yang akan dipelajari dan langkah-langkah pembelajaran yang akan dilaksanakan.

$\mathrm{F} 12=$ Indikator $\mathrm{F}$ deskriptor 1 dan 2; Indikator F = Mengorganisasikan siswa ke dalam kelompok-kelompok belajar; Deskriptor 1 = Meminta siswa untuk duduk dalam kelompoknya; dan Deskriptor $2=$ Memberikan LAS kepada masing-masing siswa.

G123456 = Indikator G descriptor 1, 2, 3, 4, 5, dan 6; Indikator $\mathrm{G}=$ Membimbing dan memfasilitasi diskusi kelompok; Deskriptor 1= Meminta siswa mencermati permasalahan dalam LAS dan membantu siswa mengkonstruksi pengetahuannya (Constructivism); Deskriptor 2 = Mengarahkan dan membimbing siswa dalam melakukan kegiatan menemukan (Inquiry, Learning Community); Deskriptor 3 = Guru menerapkan unsur bertanya kepada siswa dalam melaksanakan kegiatan-kegiatan yang disajikan dalam LAS (Questioning); Deskriptor $4=$ Guru meminta perwakilan kelompok mempresentasikan hasil diskusi kelompok (Modelling); Deskriptor $5=$ Guru memberikan kesempatan kepada kelompok lain untuk menanggapi hasil diskusi kelompok yang telah dipresentasikan; dan Deskriptor $6=$ Memberikan tanggapan terhadap hasil diskusi kelompok yang telah dipresentasikan.

$\mathrm{H} 12=$ Indikator $\mathrm{H}$ deskriptor 1 dan 2; Indikator $\mathrm{H}=$ Menyimpulkan pelajaran (Reflection); Deskriptor $1=$ Membimbing siswa membuat kesimpulan; dan Deskriptor $2=$ Merangkum kesimpulan yang telah disampaikan siswa.
$\mathrm{I} 1=\quad$ Indikator $\mathrm{I}$ deskriptor 1 ; Indikator $\mathrm{I}=$ Mengevaluasi pemahaman siswa (Authentic Assesment); Deskriptor $1=$ Memberikan tes formatif untuk mengukur ketercapaian indikator pengetahuan dan keterampilan siswa.

$\mathrm{J} 12=$ Indikator $\mathrm{J}$ deskriptor 1 dan 2; Indikator $\mathrm{J}=$ Merencanakan kegiatan tindak lanjut; Deskriptor $1=$ Guru memberikan pekerjaan rumah (PR); dan Deskriptor 2 = Meminta siswa mempelajari materi pelajaran untuk pertemuan selanjutnya.

Catatan: "Setiap deskriptor yang terlaksana sesuai dengan perencanaan diberi skor 10; dan yang tidak sama sekali terlaksana sesuai dengan perencanaan diberi skor 0".

Dari Gambar 1 dapat dilihat bahwa aktivitas guru pada pertemuan pertama (P1) dengan 10 indikator dan 19 deskriptor (A12, B1, C1, D1, E1, F12, G123456, H12, I1, dan J12) diperoleh hasil pengamatan; untuk (1) indikator A12, C1, D1, E1, F2, G1456, H1, I1, J12 sudah terlaksana sesuai dengan perencanaan; dan (2) indikator B1, F1, G23, dan H2 belum terlaksana sesuai dengan perencanaan. Hal ini terlihat dari hasil pengamatan (1) pada indikator B deskriptor 1, yakni guru memotivasi siswa dengan memberikan contoh yang relevan dengan materi yang sedang dipelajari sudah terlaksana, namun belum semua siswa dapat memperhatikan contoh (gambargambar himpunan yang diberikan) dengan focus, karena gambar yang diperhatikan oleh guru waktunya relatif singkat, sehingga tidak semua siswa dapat melihat dengan jelas; sebaiknya gambar-gambar itu dikemas dalam satu karton manila, baru ditempel di papan tulis; (2) pada indikator F deskriptor 1, yakni meminta siswa untuk duduk dalam kelompoknya sudah terlaksana, tetapi guru kurang tegas dalam menentukan posisi siswa untuk setiap kelompok, sehingga waktu yang digunakan terlalu lama; (3) pada indikator $\mathrm{G}$ deskriptor 2, yakni mengarahkan dan membimbing siswa dalam melakukan kegiatan menemukan (Inquiry, Learning Community) sudah terlaksana, namun guru terlalu banyak memberikan bimbingan dalam kegiatan menemukan konsep dan deskriptor 3, yakni guru menerapkan unsur bertanya kepada siswa dalam melaksanakan kegiatan-kegiatan yang disajikan dalam LAS (Questioning) sudah terlaksana, namun hanya beberapa siswa saja yang berani menanyakan rumus apa yang digunakan untuk menyelesaikan soal itu; (4) pada indikator $\mathrm{H}$ deskriptor 2, yakni merangkum kesimpulan yang telah disampaikan siswa sudah terlaksana, namun akan lebih baik jika kesimpulan ditulis di papan tulis, 
sehingga semua siswa dapat melihat dan memikirkannya.

Pada pertemuan kedua (P2) dan ketiga (P3) dengan indikator dan deskriptor yang sama, diperoleh hasil pengamatan untuk semua indikator dan deskriptor telah terlaksana sesuai dengan perencanaan. Hal ini terlihat dari nilai deskriptor pada pertemuan kedua (P2) dan ketiga (P3); pada masingmasing indikator dan descriptor bernilai sama, sehingga dapat dikatakan bahwa aktivitas guru pada siklus 1 sudah terlaksana sesuai dengan perencanaan.

Gambar 1 juga menunjukkan bahwa aktivitas guru pada ketiga pertemuan berikutnya (P4, P5, P6) dengan 10 indikator dan 19 deskriptor (A12, B1, C1, D1, E1, F12, G123456, H12, I1, dan J12) diperoleh hasil pengamatan, yaitu guru sudah melaksanakan semua kegiatan pembelajaran sesuai dengan perencanaan. Hal ini terlihat dari nilai deskriptor ketiga pertemuan berikutnya (P4, P5, P6); pada masing-masing indikator dan deskriptor bernilai sama, sehingga dapat dikatakan bahwa aktivitas guru pada siklus 2 sudah terlaksana sesuai dengan perencanaan.

Hasil analisis deskriptif data aktivitas siswa pada siklus 1 dan 2 (pertiga pertemuan) melalui implementasi pendekatan kontekstual, disajikan pada Gambar 2.

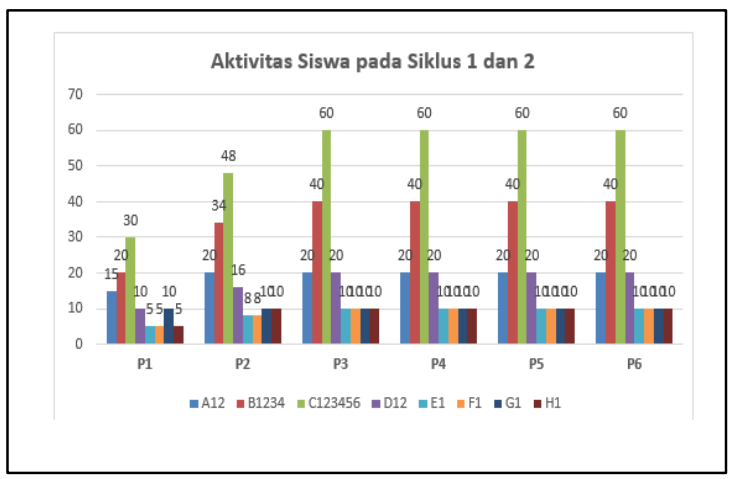

Gambar 2. Aktivitas Siswa pada Siklus 1 dan 2

Melalui Implementasi Pendekatan Kontekstual

Keterangan:

$\mathrm{A} 12=\quad$ Indikator A deskriptor 1 dan 2; Indikator $\mathrm{A}=$ Menyiapkan diri secara psikis dan fisik untuk mengikuti proses pembelajaran; Deskriptor $1=$ Siswa menyiapkan diri mengikuti proses pembelajaran dan membaca doa; Deskriptor 2 = Siswa memberikan informasi tentang kehadiran siswa

B1234 = Indikator B deskriptor 1, 2, 3, 4; Indikator $\mathrm{B}=$ Merespon informasi yang diberikan; Deskriptor $1=$ Siswa memberi tanggapan terhadap motivasi yang disampaikan guru; Deskriptor 2 = Siswa memberi tanggapan terhadap apersepsi yang disampaikan guru; Deskriptor 3 = siswa mendengarkan penjelasan guru tentang tujuan pembelajaran; Deskriptor $4=$ Siswa mendengarkan penjelasan guru tentang cakupan materi yang akan dipelajari dan langkah-langkah pembelajaran yang akan dilaksanakan.

$\mathrm{C} 123456$ = Indikator $\mathrm{C}$ deskriptor 1, 2, 3, 4, 5, 6; Indikator $\mathrm{C}=$ Melakukan diskusi kelompok dalam mengerjakan LAS; Deskriptor 1 = Siswa menempati kelompok yang telah ditentukan guru (Learning Community); Deskriptor $2=$ Siswa menerima LAS dan mendengarkan arahan dari guru; Deskriptor $3=$ Mengamati ilustrasi masalah yang ada pada LAS dan mengkonstruksi pengetahuannya (Constructivism); Deskriptor $4=$ Siswa berdiskusi dengan kelompok masingmasing dalam mengerjakan LAS (Learning Community); Deskriptor $5=$ Mengkonstruksikan pengetahuan melalui kegiatan menemukan mengikuti langkah-langkah yang ada (Constructivism, Inquiry); Deskriptor $6=$ Bertanya kepada guru jika kelompok mengalami kesulitan dalam mengerjakan LAS (Questioning).

D12 $=$ Indikator D deskriptor 1, 2; Indikator D = Mempresentasikan hasil kerja kelompok; Deskriptor 1 = Perwakilan siswa mempresentasikan hasil diskusi kelompoknya (Modelling); Deskriptor 2 $=$ Siswa dari kelompok lain memberikan tanggapan terhadap hasil diskusi kelompok yang telah dipresentasikan.

$\mathrm{E} 1=\quad$ Indikator $\mathrm{E}$ deskriptor 1; Indikator E = Menyimpulkan materi yang telah dipelajari (Reflection); Deskriptor $1=$ Siswa menyimpulkan materi pembelajaran yang telah berlangsung dibantu dengan bimbingan guru.

$\mathrm{F} 1=\quad$ Indikator $\mathrm{F}$ deskriptor 1 ; Indikator $\mathrm{F}=$ Evaluasi (Authentic Assesment); Deskriptor $1=$ Siswa mengerjakan tes formatif yang diberikan oleh guru. 
$\mathrm{G} 1=$

Indikator $\mathrm{G}$ deskriptor 1; Indikator $\mathrm{G}=$ Merespon kegiatan tindak lanjut; Deskriptor 1 = Siswa mencatat atau menandai tugas individu berupa PR.

$\mathrm{H} 1=$ Indikator $\mathrm{H}$ deskriptor 1; Indikator $\mathrm{H}=$ Menyimak informasi tentang materi selanjutnya; Deskriptor $1=$ Menyimak rencana pembelajaran yang disampaikan guru untuk pertemuan berikutnya.

Catatan: "Setiap deskriptor yang terlaksana sesuai dengan perencanaan diberi skor 10; yang terlaksana tetapi belum sesuai dengan perencanaan, skornya disesuaikan dengan kualitas aktivitas yang dilakukan siswa; dan yang tidak sama sekali terlaksana sesuai dengan perencanaan diberi skor 0 ".

Gambar 2 menunjukkan bahwa aktivitas siswa pada pertemuan pertama (P1) dengan 8 indikator dan 18 deskriptor (A12, B1234, C123456, D12, E1, F1, G1, H1) diperoleh hasil pengamatan: (1) indikator A2, dan G1 sudah terlaksana sesuai dengan perencanaan; dan (2) indikator A1, B1234, C123456, D12, E1, F1, dan H1 belum terlaksana sesuai dengan perencanaan. Hal ini terlihat dari hasil pengamatan (1) pada indikator A deskriptor 1, yakni siswa menyiapkan diri mengikuti proses pembelajaran dan membaca doa sudah terlaksana, tetapi masih banyak siswa yang bermain-main ketika ketua kelas menyiapkan temannya; (2) pada indikator $\mathrm{B}$ : deskriptor 1, yakni siswa memberi tanggapan terhadap motivasi (gambar) yang disampaikan oleh guru sudah terlaksana, namun siswa berebutan melihat gambar himpunan yang diberikan karena 4 siswa hanya mendapat 1 gambar; deskriptor 2 , yakni siswa memberi tanggapan terhadap apersepsi yang disampaikan oleh guru sudah terlaksana, tetapi hanya 1 siswa saja yang aktif menanggapi (menjawab) pertanyaan guru dan yang lain belum fokus untuk belajar; deskriptor 3, yakni siswa mendengarkan penjelasan guru tentang tujuan pembelajaran sudah terlaksana, tetapi masih banyak siswa yang tidak memperhatikan penyampaian tujuan pembelajaran; deskriptor 4, yakni siswa mendengarkan penjelasan guru tentang cakupan materi yang akan dipelajari dan langkah-langkah pembelajaran yang akan dilaksanakan sudah terlaksana, namun hanya beberapa siswa yang memperhatikan dan menyimak penjelasan guru; (3) pada indikator C deskriptor 1, yakni siswa menempati kelompok yang telah ditentukan guru (Learning Community) sudah terlaksana, tetapi waktu yang digunakan siswa untuk menempati kelompoknya terlalu lama; deskriptor 2, yakni siswa menerima LAS dan mendengarkan arahan dari guru sudah dilaksanakan, tetapi hanya beberapa siswa saja yang menyimak arahan dari guru, walaupun semua siswa sudah menerima LAS yang diberikan guru; deskriptor 3, yakni mengamati ilustrasi masalah yang ada pada LAS dan mengkonstruksi pengetahuannya (Constructivism) sudah terlaksana, tetapi masih sebahagian kecil (beberapa) siswa saja yang sudah dapat memahami masalah dengan baik; deskriptor 4, yakni siswa berdiskusi dengan kelompok masing-masing dalam mengerjakan LAS (Learning Community) sudah terlaksana, tetapi masih beberapa kelompok yang berdiskusi dengan temannya dalam mengerjakan LAS; deskriptor 5, yakni mengkonstruksi pengetahuan melalui kegiatan menemukan, mengikuti langkah-langkah yang ada (Constructivism, Inquiry) sudah terlaksana, tetapi masih beberapa kelompok yang sudah dapat mengkonstruksi pengetahuannya melalui kegiatan menemukan konsep; deskriptor 6 , yakni bertanya kepada guru jika kelompok mengalami kesulitan dalam mengerjakan LAS (Questioning) sudah terlaksana, walaupun hanya beberapa kelompok yang sudah melakukannya; (4) pada indikator D deskriptor 1, yakni perwakilan siswa mempresentasikan hasil diskusi kelompoknya (Modelling) sudah terlaksana, walaupun baru 2 kelompok (kelompok 1 dan 3) yang maju mempresentasikan hasil diskusinya; deskriptor 2, yakni siswa dari kelompok lain memberikan tanggapan terhadap hasil diskusi kelompok yang telah dipresentasikan sudah terlaksana, tetapi baru 1 kelompok (kelompok 2) yang memberi tanggapan terhadap hasil diskusi kelompok 3; (5) pada indikator E deskriptor 1, yakni siswa menyimpulkan materi pembelajaran yang telah berlangsung dibantu dengan bimbingan guru, sudah terlaksana walaupun kesimpulan yang dibuat siswa masih tersendat-sendat; (6) pada indikator $\mathrm{F}$ deskriptor 1 , yakni siswa mengerjakan tes formatif yang diberikan guru, sudah terlaksana, tetapi masih beberapa siswa saja yang sudah mengerjakan secara mandiri, yang lain mengerjakannya secara bersama-sama (berdiskusi); dan (7) pada indikator $\mathrm{H}$ deskriptor 1, yakni menyimak rencana pembelajaran yang disampaikan guru untuk pertemuan berikutnya sudah terlaksana, walaupun hanya beberapa siswa saja yang baru menyimaknya.

Pada pertemuan kedua (P2) dengan indikator dan deskriptor yang sama, diperoleh hasil pengamatan: (1) indikator A12, B3, G1, dan H1 sudah terlaksana sesuai dengan perencanaan; dan (2) indikator B124, C123456, D12, E1, dan F1 belum terlaksana sesuai dengan perencanaan, tetapi sudah ada perbaikan (peningkatan) proses pembelajaran. 
Hal ini dapat dilihat dari hasil pengamatan (1) pada indikator B deskriptor 1, yakni siswa memberi tanggapan terhadap motivasi (gambar) yang disampaikan oleh guru sudah terlaksana, dan siswa tidak berebutan lagi (sudah fokus) untuk melihat gambar-gambar himpunan, karena gambar tersebut sudah ditempelkan guru di papan tulis, sehingga dapat dilihat dengan jelas oleh semua siswa; deskriptor 2, yakni siswa memberi tanggapan terhadap apersepsi yang disampaikan guru sudah terlaksana, walaupun baru 2 sampai 3 siswa saja yang aktif menanggapi (menjawab) pertanyaan guru dan yang lain belum fokus untuk belajar; deskriptor 4, yakni siswa mendengarkan penjelasan guru tentang cakupan materi yang akan dipelajari dan langkah-langkah pembelajaran yang akan dilaksanakan sudah terlaksana, walaupun masih ada beberapa siswa yang belum memperhatikan dan menyimak penjelasan guru; (2) pada indikator C deskriptor 1, yakni siswa menempati kelompok yang telah ditentukan guru (Learning Community) sudah terlaksana, tetapi masih ada beberapa siswa yang lambat menempati kelompoknya; descriptor 2, yakni siswa menerima LAS dan mendengarkan arahan dari guru sudah terlaksana, tetapi masih ada beberapa siswa yang belum menyimak arahan dari guru, walaupun semua siswa sudah menerima LAS yang diberikan guru; deskriptor 3, yakni mengamati ilustrasi masalah yang ada pada LAS dan mengkonstruksi pengetahuannya (Constructivism) sudah terlaksana, tetapi baru sebahagian besar siswa dapat memahami masalah dengan baik; deskriptor 4, yakni siswa berdiskusi dengan kelompok masing-masing dalam mengerjakan LAS (Learning Community) sudah terlaksana, tetapi baru sebahagian besar siswa dalam kelompoknya berdiskusi dengan temannya dalam mengerjakan LAS; deskriptor 5, yakni mengkonstruksikan pengetahuan melalui kegiatan menemukan, mengikuti langkah-langkah yang ada (Constructivism, Inquiry) sudah terlaksana; sudah hampir semua kelompok dapat mengkonstruksi pengetahuannya melalui kegiatan menemukan konsep; hanya tinggal satu kelompok saja yang belum dapat mengkonstruksi pengetahuannya; deskriptor 6 , yakni bertanya kepada guru jika kelompok mengalami kesulitan dalam mengerjakan LAS (Questioning) sudah terlaksana; sudah hampir semua kelompok melakukannya, walaupun masih ada satu kelompok yang belum aktif bertanya; (3) pada indikator D deskriptor 1, yakni perwakilan siswa mempresentasikan hasil diskusi kelompoknya (Modelling) sudah terlaksana, tetapi baru 3 kelompok (kelompok 1, 3, dan 6) yang maju mempresentasikan hasil diskusinya; deskriptor 2, siswa dari kelompok lain memberikan tanggapan terhadap hasil diskusi kelompok yang telah dipresentasikan sudah terlaksana, tetapi baru 2 kelompok (kelompok 4 dan 5) yang memberi tanggapan terhadap hasil diskusi kelompok 1 dan 6; (4) pada indikator E deskriptor 1, yakni siswa menyimpulkan materi pembelajaran yang telah berlangsung dibantu dengan bimbingan guru, sudah terlaksana; kesimpulan yang dibuat siswa sudah bagus (tidak tersendat-sendat lagi) tetapi baru 2 siswa yang mewakili teman-temannya; dan (5) pada indikator $\mathrm{F}$ deskriptor 1, yakni siswa mengerjakan tes formatif yang diberikan guru, sudah terlaksana, walaupun masih terdapat beberapa siswa yang belum bisa mengerjakan tes tersebut secara mandiri (dikerjakan secara berdiskusi).

Pada pertemuan ketiga (P3) dengan indikator dan deskriptor yang sama, diperoleh hasil pengamatan untuk semua indikator dan deskriptor telah terlaksana sesuai dengan perencanaan. Hal ini terlihat dari nilai descriptor pada pertemuan ketiga (P3); pada masing-masing indikator dan deskriptor bernilai sama, sehingga dapat dikatakan bahwa aktivitas siswa pada siklus 1 sudah terlaksana sesuai dengan perencanaan.

Gambar 2 juga menunjukkan bahwa aktivitas siswa pada ketiga pertemuan berikutnya (P4, P5, P6) dengan 8 indikator dan 18 deskriptor (A12, B1234, C123456, D12, E1, F1, G1, dan H1) diperoleh hasil pengamatan, yaitu siswa sudah melaksanakan semua kegiatan pembelajaran sesuai dengan perencanaan. Hal ini terlihat dari nilai deskriptor ketiga pertemuan berikutnya (P4, P5, P6); pada masing-masing indikator dan deskriptor bernilai sama, sehingga dapat dikatakan bahwa aktivitas siswa pada siklus 2 sudah terlaksana sesuai dengan perencanaan.

Hasil analisis deskriptif terhadap data hasil belajar matematika siswa dari skor dasar (SD) ke ulangan harian 1 (UH1) dan ulangan harian 2 (UH2) melalui implementasi pendekatan kontekstual, disajikan pada Gambar 3.

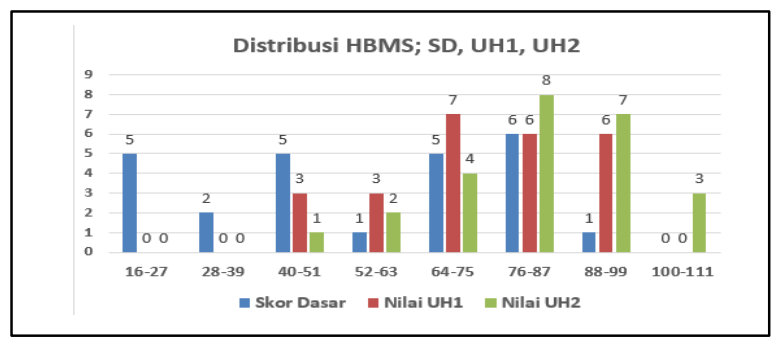

Gambar 3. Distribusi Hasil Belajar Matematika Siswa dari SD, UH1, UH2 Melalui Implementasi Pendekatan Kontekstual 
PRINSIP Pendidikan Matematika

Volume 1, Nomor 1, November 2018

Dari Gambar 3 dapat dilihat bahwa jumlah siswa yang mencapai kriteria ketuntasan minimal (KKM) pada skor dasar (SD) sebanyak 7 siswa (28\%); hal ini berarti bahwa masih ada 18 siswa lagi (72\%) yang belum mencapai KKM (76) . Pada UH1, jumlah siswa yang mencapai KKM sebanyak 12 siswa (48\%); hal ini berarti bahwa masih ada 13 siswa lagi (52\%) yang belum mencapai KKM. Selanjutnya, jumlah siswa yang mencapai KKM pada UH2 sebanyak 18 siswa (72\%); hal ini berarti bahwa masih ada 7 siswa lagi (28\%) yang belum mencapai KKM yang telah ditetapkan sekolah (76). Gambar 3 juga memperlihatkan bahwa setelah tindakan terjadi peningkatan hasil belajar matematika siswa dari SD ke UH1 dan dari UH1 ke UH2. Hal ini dapat dilihat dari terjadinya perubahan hasil belajar matematika siswa menjadi lebih baik, yang ditandai dengan meningkatnya jumlah siswa mencapai KKM dari SD ke UH1 dan dari UH1 ke UH2. Hal ini menunjukkan bahwa implementasi pendekatan kontekstual dapat meningkatkan hasil belajar matematika siswa kelas VII-4 SMP Muhammadiyah 1 Pekanbaru.

\section{SIMPULAN}

Berdasarkan hasil dan pembahasan, disimpulkan bahwa implementasi pendekatan kontekstual dapat memperbaiki proses pembelajaran dan meningkatkan hasil belajar matematika siswa kelas VII-4 SMP Muhammadiyah 1 Pekanbaru pada materi himpunan. Untuk prospek ke depan dalam implementasi pendekatan kontekstual; disarankan kepada guru, yakni ketika siswa mengalami kesulitan untuk membangun dan mengembangkan pengetahuannya (higher order thinking), maka guru harus siap memberikan scaffolding (baik secara lisan maupun tulisan) kepada siswa, sehingga siswa dapat memahami konsep dari materi yang diajarkan. Hal ini dapat mengakibatkan siswa lebih terampil dalam menyelesaikan permasalahan; baik yang ada dalam LKS maupun ketika mengerjakan soal-soal ujian. Untuk pengambilan kebijakan, disarankan pendekatan kontekstual dijadikan sebagai salah satu alternatif pembelajaran untuk memperbaiki proses pembelajaran dan meningkatkan hasil belajar matematika siswa, khususnya pada materi himpunan dan umumnya pada materi yang memuat soal cerita berkaitan dengan kehidupan sehari-hari yang bersifat kontekstual.

\section{DAFTAR PUSTAKA}

Arikunto, S. (2012). Penelitian Tindakan Kelas. Jakarta: Bumi Aksara.

Permendikbud. (2014). Peraturan Menteri Pendidikan dan Kebudayaan Republik Indonesia Nomor 58 Tahun 2014 tentang Kurikulum 2013 Sekolah Menengah Pertama/Madrasah Tsanawiyah. Jakarta: Kemendikbud.

Permendiknas. (2007). Peraturan Menteri Pendidikan Nasional Republik Indonesia Nomor 41 Tahun 2007 tentang Standar Proses untuk Satuan Pendidikan Dasar dan Menengah. Jakarta: Depdiknas.

Soedjadi, R. (2000). Kiat Pendidikan Matematika di Indonesia. Jakarta: Dirjen Pendidikan Nasional.

Trianto. (2014). Mendesain Model Pembelajaran Inovatif, Progressif dan Kontekstual. Jakarta: Kencana. 